\title{
Prospects of Tourism Development on the Royal Domains of North Shewa
}

\author{
Abraham Kidane Tesfaye \\ Department of Tourism Management, Debre Berhan University, Amhara Regionm, Ethiopia \\ Email address: \\ abrishkid@gmail.com \\ To cite this article: \\ Abraham Kidane Tesfaye. Prospects of Tourism Development on the Royal Domains of North Shewa. Journal of Investment and \\ Management. Vol. 8, No. 2, 2019, pp. 32-39. doi: 10.11648/j.jim.20190802.11
}

Received: February 15, 2019; Accepted: March 28, 2019; Published: April 13, 2019

\begin{abstract}
North Shewa is one of the arenas of Ethiopian history and cultures. Nevertheless, its heritages are not only unknown to the large public but they benefit little to the local development and to the nation. This paper intends to identify the cultural and natural heritages for tourism development in Basso-Warana districts. The data are collected through reviewing written sources, interviewing the local people and personal observations of the researchers. The research has identified major sites namely the historical and cultural heritages of king Shale Selassie (1813-40) palace, the birth place of king Menilek II (1889-1913), and the Gobena cave and his residence at Alam Katama in Aman-Gult kabala (small administrative unit) Besides, there are traditional games that can be re-enacted for tourism development. The research reveals the main prospects and challenges of the sites for their development to tourist destinations. It recommends the short and long term tourist development plan particularly for the Angollala royal seat, Gobena cave and Alam Katama.
\end{abstract}

Keywords: Angollela, Gobena Cave, King Shale Selassie, Tourism Development

\section{Introduction}

The research project of identifying and developing heritage resources of Angollala -Ṭera and Bāsso-Warāna districts was conceived by the team members in 2013. The project envisaged firstly to explore the tourism resources in two places, Angollala, and Aman-Gult (Basso). It also aims at identifying viable heritage resources to develop tourist destination at the study areas. Thus the Angollala village comprises the history and archaeological sites; namely King Shale Selassie (1813-1840) ruined palace, the church of Kidana Mehret and the birth place of King Menilek II. Aman-Gult designates the descendants of ras Gobena. His ruined palace at Alam-Katama occupies the historical vestiges of Aman-Gult. Besides, the Gobena cave is a natural grotto that turned out to a place of refugee during distress time in the Shewan kingdom (1696-1889). Gobena cave, along with the scenic beauty of the Valley of Abdella River, has an impressive natural attraction in the area.

Thus, the study investigated the particularities of these two sites from the perspectives of historical, cultural and natural tourism resources that would help to develop tourism destination for the benefits of the local communities.

\section{Materials and Methods}

This paper employed three different sources. The first sources were historical documents such as traveller accounts, articles, journals and books which used to narrate the history of the historical places, the life of the dignitaries, and the cultural values of the then people of the areas. The second group of sources came from key informant interview which supplemented and sometimes used to triangulate the data obtained from written materials. The last but not the least techniques used to gather data was personal observations or field visit of the sites which helped to view the existing landscapes, the ruins, the infrastructures and the culture of the community in the areas. Thus, it assisted to propose what kind of tourism development could be formed. Based on the above used methods, recommendation and conclusion were drawn.

\section{Literature Review}

Tourism development has been the center of discussion among scholars, destination developers and policy makers. 
The development is apparently touched upon issues like employment creation, poverty alleviation, and community empowerment. However, the issues depend on the level of the destination whether it is well developed or underway for development. Thus, there is a possible distinction between the already known destination and on the process to become a tourism sites. As a result, the focus of both destinations is differed since the stage of development they are in quite different. For example, the sites being already availed for tourism consumption, the focus tends to be on promotion, destination management and human resource development [1]. On the other hand, the area which is at the initial stage of identifying ones resources, the focus will apparently been on the potential of the area for tourism development, the type of tourism resources and the impact of the tourism development if it is properly designed and implemented tourism development. In this regard, the community becomes the center of the development in terms participation and empowerment [2].

\section{Tourism Contributions}

Tourism is one of the business sectors which grow steadily throughout the globe more than ever. According to United Nation World tourism Organization, tourism's importance in every aspect becomes grandiose in the world. Its contribution to global GDP in terms of direct, indirect and induced impacts is $9 \%$. In every eleven jobs one job is created by tourism. While there were more than a billion international tourists, the tourism receipts were more than a trillion USD in 2013 [3]. In addition, speaking of export earning tourism is the first export earner for 60 countries of the world [4].

In developing countries, the contribution of tourism to the host economy is immense. For $83 \%$ of less developed countries, tourism is a main service sector which brings hard currency. Thus, tourism has been an important economic sector from which many poor countries have been shown growth in this sector consistently. It is observable in the growth of world tourism industry. While in poor countries international tourism has grown by $9.5 \%$, the world tourism growth have been only $4.6 \%$ in a year [4]. According to the UNWTO, the growth of tourism in Africa and Asia and the Pacific were 5.6\% and $6.0 \%$ respectively, in 2013. Therefore, tourism has been continuing to grow and become the source of hard currency to many poor countries of the world.

Like other developing countries, tourism is steadily growing in Ethiopia. The country has been gaining its due share from tourism, even though the benefits are not proportionate with its tourism resources endowments. In the last two decades the only scenario that exhibited the decline of tourism was during the Ethio-Eritrean war. After 2000, the number of international tourist arrivals begun to increase again. In 2010, international tourists who came to Ethiopia were counted 468,000 . The following year, the number of arrivals reached 523,000 which mounted by $11,7 \%$ from the previous year. In terms of tourism receipts, the country accrued 522 and 758 million USD in 2010 and 2011 respectively [4]. The share of tourism takes up $40.1 \%$ in the export economy of Ethiopia. In addition, tourism and travel is directly supported 985,500 jobs or $3.8 \%$ of total employment [5].

\section{i. Tourism Resources}

Tourists can come to the host country if a given country or place has to offer something for tourism consumption. It simply mean that the given country or place must have the tourism resources to entice tourists. As Chiranjeev puts it, these are scenic factors, cultural factors, way of life, entertainment and amusement and climate. Any or several of these can lure visitors to a destination [6]. The three places which have identified for tourism development exhibits the scenic, cultural and historical endowments. Thus, these resources can be developed into tourist attractions.

\section{ii. Tourism as poverty alleviator}

Ethiopia is a poor country which is combating to eradicate poverty. One of the sectors Ethiopia wants to engage herself in tourism because of the aspiration of the government for reducing poverty impacts [7]. Different strategies and policies have been introduced to guide and gain more benefits from the tourism industry. One of the recent works in this regard is the promulgation of Ethiopian Tourism Development Policy, which is envisioned to contribute its share to the country's development by aligning itself in the eradication of poverty [8]. As it has shown, the tourism policy itself focuses on the elimination of poverty through creating employment opportunities through tourism development. In other word, tourism still plays a great role in reducing destituteness in developing country thorough creation of employment. As Chiranjeev puts it the tourism industry can create multiple employment opportunities [6]. It is also recognized that a primary path out of poverty is through employment [7].

iii. Tourism as Employment creator

Tourism is a labour intensive industry which particularly hires a large proportion of women. Besides, it opens wider opportunities for small scale enterprises [9]. It is conspicuous that as tourism is a diverse industry so that it creates a job opportunities to myriads of people be it skilled and nonskilled alike. As it is stated in a book titled "Tourism: principles, practices, philosophies", the employment opportunities of Tourism can be seen broadly as direct and indirect ones. Among the direct employer Firms are hotels, restaurants, resorts and others of which employees are in contact with tourists and provide the tourist experience. Employees of firms providing goods and services to the direct employment firms, such as construction firms, and restaurant suppliers, create indirect employment [10].

There are other areas of employment opportunities which are created by tourism related activities. Self- employments like providing accommodation services, selling food and beverages by the locals to tourists are other forms of employment. More to the point, craftsmen, traders and raw material suppliers are also engaged themselves in producing and selling handicrafts to tourists [11]. Therefore, tourism is not only open chance for employment in firms, but also it creates business opportunities where locals can be selfemployed. According to WTO, nearly a million people in 
Ethiopia employed by travel and tourism in 2014.

iv. Tourism as a means for heritage conservation

It is apparent that heritages can be preserved because of their different values. Heritage values can be broadly seen in economic and non- economic terms. Both can be motivating factors for conservation and protection of a given heritage. However, if the heritage is developed to attract tourists, the benefits accrued form tourism can strengthen the conservation and protection of the resources while supporting the local livelihood.

v. Geotourism as a tourism product

Geotourism is rising as a new global occurrence. In the 1990 's an attempt was made by a certain scholar to give a definition for geotourism. The definition was further developed and refined by different scholars afterwards. This was kept defined and expanded during the first decade of the 21 century. Currently, the widely used definition of geotourism has been given by Newsome and dowling, it has been defined as:

'Geotourism is a form of natural area tourism that specifically focuses on geology and landscape. It promotes tourism to geosites and the conservation of geo-diversity and an understanding of earth sciences through appreciation and learning. This is achieved through independent visits to geological features, use of geo-trails and view points, guided tours, geoactivities and patronage of geosite visitor centres' [12].

As the definition states that geotourism encompasses a number of aspects. The main attraction of geotourism is the natural areas particularly the geological features and landscapes of the given area. It also endorses three important things namely the consumption of the geosites for tourism, the conservation the geo-diversity of this sites and the creation of understanding about earth science through the abovementioned ways. Caves are one of geological features.

Caves are explored for tourist destinations. Many countries have done something to exploit caves for tourism consumption. In this regard, countries which have gone a long distance comparing to other countries are Brazil, Croatia, and Oman to name a few. In Croatia, [13] there are caves which are arranged for tourists. Actually, the tailored caves are being visit by the local and international tourists. This same document stresses that the potential caves must be arranged for tourists and promoting the existed cave sites would increase the inflow of tourists.

Knowing the importance of caves as a tourist products, the government of Bulgaria has also promoted the caves through different techniques including multimedia brochure. Location, characteristics, and peculiar features of the caves have been mentioned in this brochure [14]. In contrary, Ethiopia has never given that much heed to this resources.

Geological features and landscapes are prevalent in Ethiopia. One of the aims of geotourism is to make tourists to be aware of the geological features of the visited area. In Ethiopia there are plenty of geological sites but they are not tailored to accommodate tourists. In fact, geotourism encompasses any kind of geological features. Caves are the ones that demonstrate the beauty of the natural formation of the earth. In Ethiopia, there are both natural and manmade caves. The known natural cave is Sof Umer, whereas plenty of manmade caves are found in the northern part of Ethiopia. In this regard, the resource that is found at Aman Gult i.e. the Gobena Cave exhibit geological traits with its unique landscape. This cave portrait both manmade and natural touches. Therefore, gobena cave can be developed as a geotourism site and can be even named as Gobena geosites.

\section{Results and Discussions}

\subsection{Brief Historical Tourism Resources of Angollala and Aman-Gult}

\subsubsection{Angollala: The Western Capital of King Shale Sealssie (1813-1840)}

The first our research area is Angollala which is located $11 \mathrm{~km}$ from Debre Brehan, the zonal capital. It was one of the well described place in the $19^{\text {th }}$ century during southward expansion of the Shewan kingdom (1696-1889). During this time the area was controlled under the chief of an Abbichu Oromo and later it was overtaken by ras $^{1}$ Wassan Sagad (1808-1813) to open the western territories of the kingdom of Shewa [15]. However, Angollala was permanently established as the town during the reign of King Shale Selassie (Harris: 1843). Harris remarks in his account that Angollala was founded around 1831 as the capital of the western territories and he describes a huge establishment of the king's residences in Angollala. "Angollala, on the Oromo [added] frontier, founded ten years ago [16]. Since by the reigning monarch (King Shale Selassie), is now the capital of the western portion of Shewa, and during the greater part of the year it forms his majesty's favorite place of residence. The inhabitants of the town were estimated to five-thousand residents [16].

Harris remarks pomp ceremonial welcome of the king during his arrival at Angollala and he describes the structural organization of the town as well as the palace. The palace of King Shale Selassie had six row palisades. His royal residence had two stories and it was built by foreigner Demetrious from Albania. According to Harris, Kidana Mehret church was built during King Shale Selassie near his palace.

The French diplomat, who was at court of King Shale Selassie on the same year with W. C. Harris, narrates the town was newly established by the King and houses are ordinary like other rural houses except for their huge sizes. He describes the existence of three courtyards enclosed by three high palisades to reach Angollala palace [17].

Harris described his observation entering into the interior side of the six round palisades of the royal court of King Sahle Selassie and strict supervisions of standing by armed soldiers, particularly around the interior enclosure of the king's Palace. He reported in his accounts the banquet hall

\footnotetext{
1 Head; a royal title equivalent to the rank of a duke
} 
along with different royal houses like women residences and kitchens. Harris reported two stories residential houses of King Shale Selassie was positioned in the centre of the palace compound. He called a "dove cot" (probably Amorā Kənf in Amharic today) style houses to describe the distinctive architectural structures of the residential two stories of King Shale Selassie palace [16].

Krapf remarks hundreds of slaves accompanying the king particularly females assigned to different culinary services of the palace. These female slaves were from the Gurāge and Oromo and other people, who were probably war captives [18]. The water girls had to carry all the necessary water for the King's household, and for foreigners. They were maintained at the palace. There were hundreds of women to prepare beer and hydromel and they were a number of female-slaves and a large number of male-slaves, who were engaged mostly in carrying wood [18].

The Angollala palace of king Shale Selassie consisted also handicraft workers. The French members of Saint Semonian, E. D. Combes and M. Tamisier, who visited Angollala, reported the compound of king Shale Sealssie was filled with handicraftsmen [19]. These travelers were invited to visit the handicraft workshops of Angollala in 1835. They recount that handicraftsmen workshops organized in Ankobar, Angollala and Dabra Berhan palaces. The ED. Combes and M. Tamisier admired the passion of the king in the preindustrial activities of the kingdom and they write the disciplined handicraft workers in these palaces. They recount King Shale Selassie himself invited them to visit the workshop in his palaces [19].

The King admirably broke not only the inviolable cast of the handicraftsmen in the kingdom of Shewa but he created a handicraft workshop of women in the palaces of Angollala and Ankobar. These women were free, who had their chief leader, and salaried from the treasury of the king. Most women were slaves at the services of the palaces [16].

Angollala marks important events in the diplomatic history of the $19^{\text {th }}$ century Ethiopia. King Shale Selassie signed the treaties of commerce and friendship with two colonial superpowers, United Kingdom and the French government, in Angollala. Harris signed this treat on behalf of the United Kingdom that was written in both Amharic and English languages [16]. One month later, D'Héricourt, Rochet, representing the French government signed a treaty with the King in similar ceremony at the palace of Angollala [17].

According to Harris, Angollala under King Shale Selassie was a highly animated busy town. The town served as the gate of the southward expansion of his Kingdom. His repeatedly returns to Angollala was animated in pomp. The king had also celebrated religious ceremonies in Angollala, masqal, ganna or Tamqat. He reminds in his account the traditional games of ganna that was held in the eve of the Ethiopian Christmas. He narrates the game was played on a place named after the king's meadow. On the eve of Ethiopian Christmas, January 4, 1842, the ganna game was played on the field of king Shale Sealssie between royal household and the Daj Agafari ${ }^{2}$ section servants. He remarks a playing ball was made of a cloth entered into much and the opposing team competed for three times possessions of the ball. When the ball caught thrice by opposing team, the game would be over and the team declared winner. He reports the winner had the authority to insult the defeat team for two days. The first day victory enjoyment songs were chanted by males with slandering songs against the defeated team and on the second day, the supportive females of the champion team overtake the song in similar fashion of the male [16].

Harris was invited into the celebration banquet of ganna festivity following the victory of the king's team. The victorious team had chanted mockery songs over the defeat team of the Daj Agafari and high military and religious officials.

In 1842 at Angollala, a baby boy, named Menilek was born from Hayle Melekot (later king of Shewa), the son of King Shale Selassie and the founder of Angollala and his mother was Wayzaro (Mrs.) Ejgayehu. According to the chronicle of King Menilek II was miraculously conceived from Wayzaro Ejgayehu, who was entrusted the custodian of the royal princes of the Shewan kingdom (Gebre Sealssie: 1959). The story narrates that she would have told to Queen Bezabesh, the wife of the king that she saw in her dream delivering a charismatic man mounting on a white horse. During this time, Hayle Melekot was attracted and fall in love with Ejegayehu and Menilek was conceived and born in a place called today Enqulal-Kosso, the opposite side of the Angollala palace. The chronicle further describes that Menilek was baptized at the church of Angollala but he grew at a royal village of Tamqe, 5kms north of Ankobar [16].

\subsubsection{Aman-Gult the Royal Seat of Ras Gobena}

The second important site studied in our research is the locality of Aman-Gult. It is located $22 \mathrm{kms}$ North-West of Angollala that was probably the border of the medieval district of Wagda. Muslim place names in the vicinity remind the remnants of the medieval Muslim sultanate of Shewa $\left(10^{\text {th }}-13^{\text {th }}\right)$. In the modern period, it was the political seat of one of the founding forefathers of modern Ethiopia, ras Gobena. The chronicle of Shewa mentions that ato Gobena was the ally of Abagaz Bezabeh in the eve of the scape of prince Menilek's from Maqdalā prison in 1865. But ato Gobena rebelled against Abagaz $^{3}$ Bezabeh and he remained in the cave of Azu. It is probable that ato Gobena had realized the balance of power was changing with the arrival of the prince Menilek and he submitted to prince Menilek in 1865. It seems that ato Gobena was appointed chief of his Abbiccu governorship and he identified himself as military commander in Shewan army. He had soon become a righthand of King Menilek's army and played a crucial role in the modern history of Ethiopia. He led the imperial army that acquired unprecedentedly huge territories and annexed many places in the south and south western parts of Ethiopia in the

\footnotetext{
2. Chief of the royal reception section.

3 A ruler of a district or region
} 
late $19^{\text {th }}$ century [21].

Ras Gobena, an Oromo family, who was from local chiefs in Aman-Gult and Wogda, in Shewa. Gobena was born in Aman-Gult around 1821. Even though there are no sources which give an insight into prominence in Shewa; he was believed to have built fame when he was lord of Falle. He was recognized by the local population with his great virtues of courage, strength, and leadership quality [21]. He spent much of his time moving place to place to subdue various lords of Ethiopia under the suzerainty of Emperor Menilek II [21].

According to Antonio Cecchi, an Italian traveler of the late 1870 's, seeing the growing power of the king; Gobena put all his treasure under the king's disposal. As a result, the emperor gave him the office of Agafari, master of the ceremonies, who was responsible introducing guests to king Menilek. By and large, this office was given to a trusted person. This was the first title that helped Gobena come to the leadership position at the court of the King [21].

Apart from his military activities, his private or family life remains obscure to these days. He had a famous son Wadajo who married to the daughter of Menelik [21]. It is known that following the agreement reached at the Council of Boru Meda in 1878 , ras Gobena was given a mission to establish churches across newly submitted regions. To this effect, he entrusted the task of implementing the construction to the Meslane (district governors). In the course of Menilek's expedition to the north for the purpose of getting the submission of the northern nobles after the death of Emperor Yohannes IV, ras Gobena was on his everyday duties of guarding the town and brings justice to the public. One day, shortly after he returned home, passing the whole day in receiving appeals from the people, he unexpectedly felt ill, and passed away after three days of treatment. After the grand funeral ceremony, he was buried in Dabra Libanos in July 1889 few months before the coronation of Menilek II, whom ras Gobena had served devotedly for so long time [22].

\subsection{Heritage Resources of Angollala and Aman-Gult}

\subsubsection{The Historical Vestiges of Angollala}

Angollala has already turned out to be far beyond a representation of a place name. It exposes as the home of the heroes of the creators of modern Ethiopian, king Shale Sealssie, king Menilek, ras Gobena and Fitawrari ${ }^{4}$ Gebeyhu. Angollala village exhibits the material remains of the period. The ruins of the palace of King Shale Sealassie authenticate the narratives of the European travelers in the early $19^{\text {th }}$ century. The heaps of the ruins are grouped into two main enclosures. The first enclosures present the ordinary piles of stones within the enclosures. The next enclosures separated by the old and long wall holds an underground masonry cellar. It seems the remains of foreigners' stonework. European travelers repeatedly mentioned the building of the palace of King Shale Sealssie in Angollala was led by foreign

4 Leader of the fornt in military workers. The Angollala palace ruins represent one of the peculiar remains of the royal residences of the Shewan kingdom. It will be an ideal archaeological research place of the royal residence of the Shewan kingdom and entertaining attraction.

The church of Angollala Kidana Mehret (Covenant of Mercy) is located 50 meters east of the palace of King Shale Selassie. This referential position has a semiotic implication throughout the medieval and modern periods. It is because the king prayed always facing eastward where the holy tabernacle (tabot) was located. According to our informants, the original place of the church was around 100 meters south of the actual church. The actual church is built with the help of local people in the 1976/7 under the leadership of Ato (Mr.) Haile Mesqel, the renowned resident of Debre Berhan and who was responsible for the restoration of Dabra Berhan Selassie church in the same year. It is a good example the royal church of Angollala Kidana Mehret used to acquire and preserve the ancient manuscripts. However, these manuscripts except for a few, they were regrettably looted from the church seven years ago. Fortunately, a large part of these manuscripts are today survived in microfilms in Ethiopian National Archives.

\subsubsection{Religious Ceremonial Places in Angollala}

From successive historical events, Angollala undergo different religious transitions from the medieval Shewan Muslim Sultanate influence to the Christian kingdom domain in pre- $16^{\text {th }}$ century Ethiopia. In post- $16^{\text {th }}$ century, it was overwhelmed by traditional Oromo beliefs and finally concluded in the $19^{\text {th }}$ century as the centre of the royal residence of King Shale Selassie. Christianity continued strong among the Oromo people in the area. In Angollala, therefore, religious ceremonies follow the liturgical Christian tradition. Two annual processional ceremonies are the masqal (the finding of the true cross) on Maskaram (September) 17 and timkat (the commemoration of the baptismal Jesus-Christ in the river Jordan) holds on Tir (January) 11. The baptismal commemoration is celebrated three kilometers to the northwest of the village on the board of the River Angollala. This specific place is called Yordanos (Jordan) in the image of the River Jordan in Israel. These two religious ceremonies feasted each year in public and household banquets. Boys and girls gathered to sing the traditional songs in both Amharic and Affaan Oromo. At the end of the two days timkat processional ceremonies, there is an open air horse ride game. The horse game is usually performed by men. The riding horse should be a preservation of the cavalry military practices of the old times. The young cavalry warriors before they went to war, they were trained in riding horses using sticks behind one after another. The rear rider would throw a stick to front rider and the front rider should block with his shield. After perfection on this continual training, young warriors finally demonstrate their skills before the king or the military officials. The talents of throwing spears and shielding tactics were examined during processional demonstrations. The qualified warriors were then recruited 
into the cavalry regiment.

It was these practices introduced eventually in the religious festival games. The town of Angollala had repeatedly experienced these religious processional festivals and riding horse festival games. The oral tradition describes that the religious riding horse has been seen by the festival participants with different fans. This moment was inspiring to attract young boys into the cavalry skills. The other religious ceremony is the Christmas day in tahsas (December) 29. As it has said above, the European travelers described as the ganna game. Two teams from the palace had competed and the victorious team allowed to eat at the banquet of the king accompanied by supportive singers both men and women. The oral tradition reminds the king used to reward a cup for the victorious team.

\subsubsection{Tourism Resources of Lieu de Mémoire in Angollala and Amān-Gult}

Angollala holds three prominent architects of modern Ethiopia. Menilek II and ras Gobena were born in the same vicinity and allied in the early accession of Menilek as king of Shewa in 1865. Fitawrari Gebeyhu was also part of this historical formative event. He is particularly remembered as the chief of the Ethiopian army during the Italian invasion in 1896 and identified himself as a hero. He dies at the battle of Adawa. They are still remembered in Angollala as the hero of the defense of the liberty from European colonial ambitions and the founders of modern Ethiopia. The legacies of these protagonist builders of present day of Ethiopia, has made the vicinity of Angollala their lieu de mémoire, where they are remembered in time and space.

\subsubsection{Enqulal-Kosso: The Birth Place of King Menilek II (1889-1913)}

These two individual terms, Enqulal and Kosso, jointly have no common meaning, but distinctively, they designate identified denotation in Amharic language. The former denotes egg while the latter represents a tree from which one can get medicament for parasites. However, the chronicle of King Menilek II does not name the exact birthplace of the monarch as it is described in the oral tradition. It seems that this birthplace was animated residential place of the princes of the Shewa kingdom. The mother of Menilek II, Ejigayehu was employed by Queen Bezabesh, the wife of king Shale Selassie, as a tutor to the heirs of the Shewan throne like Hayle Melkot, Seyfu Haile Michael and Darge. Except, for a small statue and rural memorial clinic named after king Menilek II, the desolate birthplace exhibits no trace of royal residences as mentioned in the chronicle of king Menilek II. In fact, it needs further archaeological studies to locate precisely the birthplace of king Menilek.

\subsubsection{Aman-Gult: A Place of the Memories of Ras Gobena}

Aman-Gult demonstrates the lieu de mémoire of ras Gobana. Both the village of Alam Katama in Aman-Gult and the natural cave of Azu are attributed to the memory of ras Gobena. The oral tradition in Aman-Gult claims that ras Gobena originated from the Sokoru village, the next adjacent kabale. Besides, the Alam Katama, where the palace of ras Gobena was established in the Aman-Gult village before it was totally ruined by the local people during the Ethiopian revolution in 1970s. The oral tradition, not only regards ras Gobena as the renowned empire builder of modern Ethiopia but also he is considered as the respected Christian religious revivalist in this locality. At least, three churches are attributed to him. The churches of Marqorios in Aman-Gult, Sokoru Maryam and Wayu Maryam would have been built under his auspices.

It is clear that the nomination of Azu cave to ras Gobena aims to elevate his political heroism of his leadership achievements in the National and local levels. He is a hero of the whole villages around Aman-Gult. That is why this village remained the gult of the descendants of Gobena family until 1974. The granddaughter of ras Gobena, Wayzaro Tsege-Maryam, Mother of Prince Mikael Emeru, constructed an elegant residential house in Aman-Gult. She built relatively a very big house in stone, probably for the homage of her grandfather. This house still serves as administrative offices of the Kabale (community). The building of the royal house by descendants of ras Gobena in Aman-Gult supports evidently the attachment of his family to this place. It is as a heritage to this locality. The house is degraded that needs renovation for the future enhancement of tourism in this area.

\subsubsection{Gobena Washa: Eye-Catching Natural Heritage}

The cave demonstrates a magnificent natural view for its visitors. On the top of the cave, small seasonal waterfalls grasp the eyes and hearts of its visitors. The attractive gorge of Abdella River particularly during harvesting season present a colorful view of the area. The cave concealed in precipitously steeped huge basaltic stones that demonstrates natural and huge walls cracked down from its ceiling rock. It is a good example how the cave would be formed from natural precipice. After climbing a small steeply walk way, the visitors face a huge opened cave invisible without a powerful torch light. Visitors who would come in the afternoon, they would take advantage of the sunlight penetration to see a certain distance inside the cave. For the darkness of the cave, it is not only the immensity of its interior but the ceiling of the cave is entirely carbonized, probably due to the burning of wood by its old inhabitants.

After stepping forward around ten meters, the visitors face small circular houses for a first surprise. Our local informant called them gottara, to mean store houses. The cave continuous more than thirty meters on forming a semicircular opening that attaches to its basement. On average, the cave measures around 30 meters east-west and around 40 meters North-South directions. Its heights vary between 1.5 to 2.5 meters. In the interior, recently built ruins of circular houses are visible. These houses built from basaltic stones available on the place.

They are attached to the ceiling of the rock. Most of the houses have small rooms attached to one another probably served for the purpose of animal enclosure or storage. 
Externally, houses are cemented with mud while the interior is tiled by the cow dung, ' around seven houses are visible. On down, warding to the limits of the north west of the cave, visitors perceive small piles of garbage of ashes thrown behind the houses that descends towards the basement. Not far from there, near a house there is an opening of a natural crack of the basement of the rock that measures around five meters long, which has also piles of ashes garbage; but the opening continues descending towards a sort of a small cavity or tunnel, which would lead to an underground opening. These piles of ashes witness obviously the long human occupation of the cave.

Who were the inhabitants of this cave? The oral tradition, describes it was inhabited by ras Gobena during his fight against Aabgaz Bezabeh (1857-1865). As it has seen above, Gobena remained in the cave until Aabgaz Bezabeh was defeated in 1865 by Nagus (King) Menilek at the battle of Gadilo-Meda. It is also plausible that the local people secreted in the Gobena cave during Italian occupation (19351941). According to the local memory, during Italian military patronages in the area, most mothers, particularly who had baby-boys were run to hide themselves from Italian view in the Gobena cave and other caves in the ravine of Abdella River. It is obvious the built houses and stores inside the Gobena cave served for hiding place during distressing times.

From our observation of the material cultures, the construction styles of houses, the ropes and potteries found in this cave attest undoubtedly very recent settlement of human occupation. However, the cave could have a long history of earlier occupations because the tradition recounts that the caves of the riverine kept many tabotat from the damages of Imam Ahamd Ibn Ibrahim in the early $16^{\text {th }}$ century. This would suggest that the Gobena cave would have been occupied from ancient times. It still serves as hiding place during violent circumstances.

It is worthy to mention here that the Aman-Gult vicinity maintains Islamic place names. A village adjacent to AmanGult and the River are named after a certain Abdella. Both place names represent Muslim background. This designation could suggest a long history of this locality would relate to the Muslim Sultanate of Shewa $\left(10^{\text {th }}-13^{\text {th }}\right.$ Century). The name Abdella reminds three Sultans of Muslim kingdom of Shewa in the $12^{\text {th }}$ and $13^{\text {th }}$ century [23]. Undoubtedly, the area of Aman-Gult, if the basic infrastructures will develop, its particular historical values, its natural views, fauna and flora permit to enhance tourism attractions in the area.

\section{Conclusion}

The research reveals obviously that the Angollala and Gobena royal seats and the Gobena cave have viable potential to develop tourism attractions in the respective areas. The royal seat of Angollala, the residence of Alam Katama and the Gobena cave in Aman-Gult can be easily developed into one tourist visiting route.

All these places have enormous potential for tourism development since they hold the reminiscence of the most known royal seats of the $19^{\text {th }}$ century in the history of Ethiopia, and the sites' heritages also attract visitor on their own right if they are developed. This research lends groundwork for the tourism development. To develop tourism sites require coordination among government, host community, investors, and development donors. In order to develop the sites into a tourism product number of activities' should be undergone in the sites. Among the main works, the construction of a one story lodge in two selected sites, trail development from the cave to the Gobena's ruined palace, clearance of the cave's inside to make passage are the core development works in the sites. For such and other activities, the project of developing tourist attractions in Angollala and Aman-Gult requires the concerted efferts of different stakeholders who should play their role in providing material and financial supports. These proposed tourism development will directly involve the rural communities of the study areas. Therefore, the development of the site will certainly generate additional income for the local communities. Furthermore, it will be serving as field laboratories for students of history, heritage studies and Tourism Management of Dabra Berhan University and related institutions at large.

\section{Recommendation}

\section{Establishing Information centre}

In both sites, in Angollala historical sites of Shale Sahlssie's palace and the Birth of King Menilek II can be developed through the creation of a cultural centre. The health Centre building established by the Association for the Memory of King Menilek II in 1986 at the birth king Menilek II is closed for more than five years. This building can be used as an information centre, where visitor could stop to visit the site. It is an ideal place to organize the photographic and portrait exhibition of the life and times of king Shale Selassie, King Menilek II, Fitawrari Gebyehu and even ras Gobena. Besides, the local living cultural values of Amhara and Oromo will be also integrated to promote the attraction areas. In the long term, this will develop to a museum of the surrounding area.

\section{Re-enactment of traditional games}

Angollala holds a fertile ground to re-enact the traditional

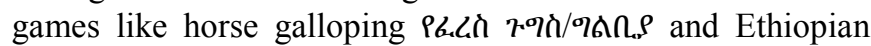
traditional "hockey" $7 \mathcal{\varsigma}$ ณ中. Horse trekking can be developed from Angollala to Amān-Gult, DebreBerhan and even Ankobar. For both galloping and Ganna game could follow the old time filed games, which are identified in the area. Firstly, the local people clothing with traditional cloths will show riding horses and playing ganna game in the selected field. Secondly, tourists accompanied by the local trainers, they can be invited to ride horses and play ganna games in the fields for easy sportive exercises of the visitors. The rules and regulations of these games can be adapted that has already developed nationally by the Ethiopian Ministry of Sport and Youth.

3. Lodge and trails development

The entertainment project will include starting tourist 
attraction sites by constructing lodges in both Angollala and Aman-Gult. It will strictly follow the house making, in the style of the Shewan architectures. One story building lodges will be constructed that encompasses ten bedrooms, private toilet and shower. Concerning infrastructure like electricity and water supply will be installed in the lodge. Bedrooms, Bar and Restaurant, Lobby and Souvenir shop will share the two story building. In addition, the project envisages the development of a trail that link Angollala, Alam Katama and Gobena Cave that will be used by trekkers and by horse gallopers. For short term period a trail pavement is recommendable to line the Gobena cave and the royal residence of ras Gobena (Alem Katama). There will be a camping ground in Aman-Gult. For camping, needed equipment will be made available to visitors. The project will deeply examine the needed impact assessment in the selected areas.

4. Infrastructural Development

Since there is no electricity in Aman-Gult, there is a possible envisaged harvesting solar energy. There is no purposely built road to the sites; thus there will be a plan to develop a trail that stretches from Gobena cave to Alam Katama and from the main road to Gobena cave. Concerning the inside part of the cave, there will be clearing to make possible a meter wide trail. Obviously, the trail will help the visitor to see the inside part of the cave safely. Different safety equipment will be provided for tourists.

\section{References}

[1] Mitchell, Jonathan and Coles, Christopher. (2009). Enhancing private sector and community Engagement in tourism services in Ethiopia. Overseas Development Institute. www.odi.org.uk

[2] Aref, Fariborz, Gill, Sarjit S \& Aref, Farshid. (2010) Tourism Development in Local Communities: As a Community Development Approach. Journal of American Science, 6 (2).

[3] UNWTO (2014). Tourism Highlights. 2014 Edition. (www.unwto.org).

[4] TIES (2005). TIES Global Ecotourism Fact Sheet. (www.ecotourism.org).

[5] WTTC (2011). Travel and Tourism: Economic Impacts of Ethiopia. 2011 (www.wttc.org).

[6] WTTC (2014). Economic Travel and Tourism: Impacts of Ethiopia. 2014 (www.wttc.org).

[7] Chiranjeev, Avinash (2008). Ecotourism Planning and Development. New Delhi: Jnanada.
[8] World Bank (2006). Ethiopia: Towards a Strategy for ProPoor Tourism Development. Report No. 38420 -ET.

[9] Minister of Tourism and Culture (2009). Tourism Development Policy. Addis Ababa.

[10] Chok, Stephanie and Macbeth, Jim (2007) Tourism as a Tool for Poverty Alleviation: A Critical Analysis of 'Pro-Poor Tourism' and Implications for Sustainability, CURRENT ISSUES IN TOURISM Vol. 10, Nos. 2\&3, 2007.

[11] Goeldner Charles R. and Ritchie, J. R. Brent (2009). Tourism: principles, practices, philosophies. ( $11^{\text {th }}$ Ed.). John Wiley \& Sons.

[12] (ITC) International Trade Centre (2010). Inclusive Tourism: Linking the Handicraft Sector to Tourism Markets. Geneva: Doc. No. SC-10r-182. E.

[13] Ross K. Dowling (2010). Geo-tourism's Global Growth. Published online: Springer-Verlag.

[14] Prakashan. Bočić, N., Lukić, A. \&Opačić, V. (2006). Management Models and Development of Show Caves as Tourist Destinations in Croatia. Unpublished internal document, University of Zagreb.

[15] Ministry of Economy, Energy and Tourism (2008). "Multimedia Catalogue of the Tourist Sites and Electronic Marketing of Destination Bulgaria" Unpublished internal Document (http://www.bgregio.eu).

[16] Gebre Sellasie WäldäArgay (1959 E. C). Tarikä Zämänä Zädagmawi Menilek: Negusä Nägäst Zä-Ityopya, Addis Ababa. pp. 38 and 40.

[17] Harris, W. C. (1844). The Highlands of Ethiopia Athiopia, London. Vol. II. pp. 149, 151 and 230.

[18] D'Héricourt, Rochet (1841). Voyage sur la cote oriental de la Mer Rouge, dans le pays d'Adal et le royaume du Choa. Paris. P. 149.

[19] Krapf, L. (1968). The Journal of Isenberg and Krapf, Travels, Researches and Missionary Labours during eighteen Year's residence in East Africa, London.

[20] Combes, E. D. and Tamisier, M. (1838). Voyage en Abyssinie: Dans le pays des Galla, de Choa et d'Ifat, Paris, Louis Desessart. pp. 349-350.

[21] Mohammed Hassan (1994). The Oromo of Ethiopia: A History 1570-1860 (Trenton: Red Sea Press. pp. 817-818.

[22] "Ras Gobena (1821-1889)." WWW// http. ethiopians.com

[23] Deresse Ayenachew (2016). "A historical overview of the Wärğəh Muslim community in the Christian highland of Šäwa." Afriques [on line] Varia, Posted on November 03, 2016, http://afriques.revues.org/1944. P. 16. 